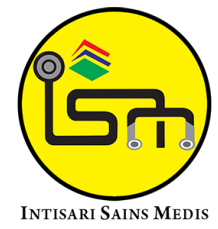

Published by Intisari Sains Medis

\section{Efek pemberian formulasi SMEDDS ekstrak biji kedelai (glycine soja) terhadap kadar LDL dan HDL pada tikus yang diinduksi jantung koroner}

\begin{abstract}
Adrian Wiryanata Gorintha', I Nengah Raka Swastika', Ni Ketut Risitani', Agung Wiwiek Indrayani ${ }^{2 *}$
\end{abstract}

'Program Studi Sarjana Kedokteran dan Profesi Dokter Fakultas Kedokteran Universitas Udayana; ${ }^{2}$ Departemen Farmakologi Fakultas Kedokteran Universitas Udayana;

\section{*Korespondensi:}

Agung Wiwiek Indrayani;

Departemen Farmakologi Fakultas Kedokteran Universitas Udayana;

agungwiwiek@unud.ac.id

Diterima: 30-10-2021

Disetujui: 27-11-2021

Diterbitkan: 07-12-2021

\section{ABSTRACT}

Introduction: Coronary heart disease is one of the national health problems that gets attention. One of the efforts to develop the treatment of coronary heart disease includes the use of natural ingredients such as soybean seed extract which contains aglycone isoflavones which affect preventing endothelial dysfunction and reducing LDL levels in the blood, where high LDL levels and low HDL levels in the blood are one of the factors. The risk of coronary heart disease. Aglycone isoflavone compounds are non-polar compounds that are difficult to dissolve in water, so they require other ingredients to increase the absorption of aglycone isoflavones, one of which is the Self Microemulsifying Drug Delivery System (SMEDDS) formulation that can help improve solubilization and access drug to lymphatic tissue.

Methods: This experimental study was conducted with a post-test only approach. The research sample used 35 white rats which were divided into the first group which was given a normal diet, the second group which was

given a high-fat diet and the third to fifth groups which were given a high-fat diet and the SMEDDS formulation of soybean seed extract. The SMEDDS formulation of soybean seed extract was administered at $200 \mathrm{mg} / \mathrm{mL}$, $300 \mathrm{mg} / \mathrm{mL}$ and $400 \mathrm{mg} / \mathrm{mL}$ using a probe for seven days, twenty-one days after rats were induced with coronary heart disease with a high-fat diet. The rat blood was then taken for analysis of LDL and HDL levels. Data were analyzed by SPSS for windows.

Results: The results showed that there was no significant difference in LDL and HDL levels from each experimental group $(p>0.05)$. This can be caused by the short period of administration of the SMEDDS formulation and the dosage of the formulation that has not been able to provide clinical effects on experimental animals.

Conclusion: The SMEDDS formulation of soybean seed extract did not show the ability to reduce LDL lizards or increase HDL levels in rats induced by coronary heart disease.

Keywords: LDL, HDL Coronary Heart Disease, SMEDDS, Soy Isoflavone Aglycone.

Cite This Article: Gorintha, A.W., Swastika, I.N.R., Risitani, N.K., Indrayani, A.W. 2021. Efek pemberian formulasi SMEDDS ekstrak biji kedelai (glycine soja) terhadap kadar LDL dan HDL pada tikus yang diinduksi jantung koroner. Intisari Sains Medis 12(3): 857-861. D01: 10.15562/ism.v12i3.1185

\title{
ABSTRAK
}

Pendahuluan: Penyakit jantung koroner merupakan salah satu masalah kesehatan nasional yang mendapat perhatian. Salah satu upaya pengembangan pengobatan penyakit jantung koroner meliputi pemanfaatan bahan alami seperti ekstrak biji kedelai yang memiliki kandungan isoflavon aglikon yang memiliki efek untuk pencegahan disfungsi endotel serta penurunan kadar LDL dalam darah, dimana tingginya kadar LDL dan rendahnya kadar HDL dalam darah sendiri merupakan salah satu faktor risiko dari kejadian penyakit jantung koroner. Senyawa isoflavon aglikon sendiri adalah senyawa non polar yang sulit untuk terlarut dalam air sehingga memerlukan bahan lain untuk meningkatkan penyerapan isoflavon aglikon, salah satunya adalah formulasi Self Microemulsifying Drug Delivery System (SMEDDS) yang dapat membantu meningkatkan solubilisasi dan akses obat ke jaringan limfatik.

Metode: Penelitian eksperimental ini dilakukan dengan pendekatan post-test only. Sampel penelitian menggunakan 35 ekor tikus putih yang dibagi menjadi kelompok pertama yang diberikan pakan normal, kelompok kedua yang diberikan pakan tinggi lemak serta kelompok ketiga hingga kelima yang diberikan pakan tinggi lemak dan formulasi SMEDDS ekstrak biji kedelai. Formulasi SMEDDS ekstrak biji kedelai 
diberikan sebanyak $200 \mathrm{mg} / \mathrm{mL}, 300 \mathrm{mg} / \mathrm{mL}$ dan $400 \mathrm{mg} / \mathrm{mL}$ dengan menggunakan sonde selama tujuh hari, dua puluh satu hari setelah tikus diinduksi penyakit jantung koroner dengan diet tinggi lemak. Darah tikus kemudia diambil untuk analisis kadar LDL dan HDL. Data dianalisis dengan SPSS untuk windows. Hasil: Hasil penelitian menunjukkan bahwa tidak terdapat perbedaan yang signifikan pada kadar LDL dan HDL dari tiap kelompok percobaan $(p>0,05)$. Hal ini dapat diakibatkan karena jangka waktu pemberian formulasi SMEDDS yang cukup singkat dan dosis formulasi yang belum dapat memberikan efek klinis terhadap hewan coba.

Simpulan: Pemberian formulasi SMEDDS ekstrak biji kedelai tidak menunjukkan kemampuan untuk menurunkan kadal LDL ataupun meningkatkan kadar HDL pada tikus yang diinduksi penyakit jantung koroner.

Kata kunci: Isoflavone aglycone kedelai, LDL, Penyakit Jantung Koroner HDL, SMEDDS.

Sitasi Artikel ini: Gorintha, A.W., Swastika, I.N.R., Risitani, N.K., Indrayani, A.W. 2021. Efek pemberian formulasi SMEDDS ekstrak biji kedelai ( $g$ lycine soja) terhadap kadar LDL dan HDL pada tikus yang diinduksi jantung koroner. Intisari Sains Medis 12(3): 857-861. D0I: 10.15562/ism.v12i3.1185

\section{PENDAHULUAN}

Penyakit jantung koroner (PJK) adalah sebuah kelainan yang diakibatkan oleh terjadinya penyumbatan pada arteri koronaria karena proses aterosklerosis yang mengganggu suplai darah yang kaya oksigen dan nutrisi yang menuju otot jantung. ${ }^{1}$ Proses aterosklerosis dimulai dengan disfungsi endotel yang distimulasi oleh keberadaan beberapa senyawa proinflamasi dan penumpukan kolesterol terutama jenis Low Density Lipoprotein (LDL) pada daerah subendotelial. Kemudian LDL yang tertahan ini akan di modifikasi menjadi Oxidized LDL (Ox LDL) yang bersifat aterogenik yang menginduksi ekspresi molekul adhesi, sehingga terjadi transmigrasi sel monosit ke subendotel. Hal ini mengakibatkan makrofag melakukan fagositosis terhadap Ox LDL dan menjadi sel busa (foam cell) yang disertai dengan pelepasan sitokin sehingga terjadi lesi aterosklerosis yang dapat berujung pada penyakit jantung jantung koroner.Selain LDL, peran dari High density lipoprotein (HDL) diketahui jugaberkontribusiterhadapperkembangan arteroskleoris, dimana penurunan kadar HDL sendiri merupakan salah satu faktor risiko dari penyakit jantung koroner (Linton et al, 2019). ${ }^{2}$ Di Indonesia sendiri menurut data dari Sample Registration System (SRS) Indonesia tahun 2014, PJK adalah penyebab kematian tertinggi kedua setelah stroke dengan persentase sebesar $12,9 \%$ dari seluruh penyebab kematian di Indonesia. ${ }^{1}$

Untuk mengurangi angka kejadian PJK, pemerintah sudah menerapkan beberapa upaya, salah satunya adalah dengan Gerakan Masyarakat Hidup Sehat (GERMAS), namun hal ini belum mampu menurunkan angka kejadian PJK. Selain itu, penggunaan obat untuk pengobatan PJK seperti Niasin ternyata memiliki beberapa efek samping, dimana dapat memicu tekanan darah rendah jika dikonsumsi dalam jangka waktu yang cukup panjang. ${ }^{1}$

Penanganan penyakit jantung koroner telah berkembang ke arah pengobatn dengan berbasis bahan alami dimana salah satunya adalah dengan memanfaatkan ekstrak dari biji kedelai sebagai salah satu solusi alternatif yang lebih murah, efektif dan mudah didapat. Di Indonesia kedelai adalah komoditas pangan utama setelah padi dan jagung. Kedelai kaya akan kandungan antioksidan isoflavone, terutama isoflavone aglycones genistein, daidzein, dan glycitein. Food and Drug Administration (FDA) telah mengakui bahwa makanan yang mengandung protein kedelai dengan asupan $25 \mathrm{~g}$ protein kedelai per hari memiliki kemampuan untuk mengurangi kolesterol (3,77\%), LDL-kolesterol (5,25\%), triasilgliserol $(7,27 \%)$ dan peningkatan serum secara signifikan HDL-kolesterol $(3,03 \%){ }^{3}$ Dimana senyawa bioaktif pada isoflavon ini yang berperan penting dalam proses penurunan LDL adalah isoflavon aglikon yang memiliki sifat non polar. ${ }^{3}$

Untuk meningkatkan bioavaibilitas dari isoflavon aglikon yang memiliki sifat non polar, diperlukan suatu strategi formulasi agar senyawa ini dapat dengan mudah larut di dalam air sehingga penyebarannya dapat menyeluruh ke seluruh tubuh. Self Microemulsifying Drug Delivery System (SMEDDS) merupakan salah satu pendekatan yang menarik dalam peningkatan kelarutan, penyerapan, dan pelepasan oral untuk obat yang memiliki kelarutan yang buruk di dalam air. ${ }^{4}$

Berdasarkan pada pemaparan di atas maka penelitian ini bertujuan untuk mengetahui pengaruh pemberian formulasi SMEDDS ekstrak biji kedelai (Glycine soja) terhadap kadar LDL dan HDL pada tikus model jantung koroner.

\section{METODE}

Penelitian ini merupakan peneliitan eksperimental yang menggunakan desain penelitian post test only experimental. Penelitian ini dilakukan di Laboratorium Farmakologi dan hewan coba biomedik terpadu serta laboratorium biokimia di Fakultas Kedokteran Universitas Udayana dari bulan Juni hingga September 2021. Hewan coba yang digunakan adalah tikus jenis rattus novergicus galur wistar jantan berjumlah 35 ekor dengan usia 6-8 minggu dengan berat badan 100-200 gram yang dibagi dalam 5 kelompok dengan jumlah di setiap kelompok 7 ekor tikus.

Hewan coba dikelompokan dengan metode simple random sampling ke dalam 5 kelompok dengan perlakuan berbeda, yaitu kelompok P1 (pakan normal), P2 (Pakan tinggi lemak), P3 (Pakan tinggi lemak + formulasi SMEDDS $200 \mathrm{mg} /$ $\mathrm{mL}$ ), P4 (Pakan tinggi lemak + Formulasi SMEDDS $300 \mathrm{mg} / \mathrm{mL}$ ) dan P5 (Pakan tinggi lemak + Formulasi SMEDDS 400 $\mathrm{mg} / \mathrm{mL}$ ). Pemberian formulasi SMEDDS 
dilakukan dengan menggunakan sonde sebanyak 1 cc sementara pemberian pakan tinggi lemak dilakukan dengan menggunakan pakan normal yang telah dicampur dengan lemak babi serta sonde kuning telur sebanyak $1 \mathrm{cc}$.

Pakan tinggi lemak diberikan selama 21 hari kemudian dilanjutkan untuk pemberian formulasi SMEDDS selama 7 hari. Seluruh data dianalisis menggunakan piranti lunak Statistical Program for Social Science (SPSS) untuk windows dengan terlebih dahulu dilakukan uji normalitas Shapiro-Wilk yang akan dilanjutkan dengan analisis one-way ANOVA bila data terdistribusi normal dan Kruskal Wallis Test bila data terdistirbudsi tidak normal.

Pembuatan formulasiSMEDDSEkstrak Biji Kedelai dimulai dengan menghaluskan biji kedelai menjadi tepung kemudian direndam dan dilakukan maserasi sehingga didapat ekstrak biji kedelai. Kemudian dilakukan penggabungan ekstrak dengan minyak, Tween 80 dan PEG 400 yang akan membentuk formulasi SMEDDS. Selanjutnya formulasi yang sudah terbentuk akan diuji nilai transmitan dari formulais ini, dimana didapat nilai transmitan mendekati satu. ${ }^{5}$

Tabel 1. Hasil pengukuran kadar HDL dan LDL hewan coba pasca perlakuan.

\begin{tabular}{ccc}
\hline & \multicolumn{2}{c}{ Rerata } \\
\cline { 2 - 3 } Kelompok Sampel & HDL & LDL \\
\hline Kelompok 1 & 55,304 & 12,569 \\
Kelompok 2 & 57,373 & 14,756 \\
Kelompok 3 & 52,721 & 16,889 \\
Kelompok 4 & 51,385 & 8,216 \\
Kelompok 5 & 48,674 & 12,847 \\
\hline
\end{tabular}

Tabel 2. Analisis bivariat kadar HDL dan LDL hewan coba pasca perlakuan pada setiap kelompok.

\begin{tabular}{ccccc}
\hline \multirow{2}{*}{ Kelompok Sampel } & \multicolumn{2}{c}{ HDL } & \multicolumn{2}{c}{ LDL } \\
\cline { 2 - 5 } & Rerata & SD & Rerata & SD \\
\hline Kelompok 1 & 55,304 & 12,757 & 12,569 & 6,38 \\
Kelompok 2 & 57,373 & 12,549 & 14,756 & 7,815 \\
Kelompok 3 & 52,721 & 11,006 & 16,889 & 8,975 \\
Kelompok 4 & 51,385 & 6,216 & 8,216 & 2,977 \\
Kelompok 5 & 48,674 & 9,955 & 12,847 & 8,633 \\
\hline p & \multicolumn{3}{c}{$0,772^{\mathrm{b}}$} \\
\hline
\end{tabular}

Keterangan: ${ }^{a}$ Analisis menggunakan Kuskal Wallis Test, ${ }^{\mathrm{b}}$ Analisis menggunakan One-Way ANOVA, *hasil dianggap signifikan jika $\mathrm{p} \leq 0,05$.

Berdasarkan analisis dengan menggunakan uji One-Way ANOVA pada kadar HDL, tidak ditemukan perbedaan rerata yang bermakna secara statistic $(p>0,05)$. Begitu pula pada variabel trigliserida, kolesterol total, dan LDL yang dianalisis dengan menggunakan Kruskal Wallis Test tidak menujukkan hasil yang bermakna secara statistik $(\mathrm{p}>0,05)$.

\section{PEMBAHASAN}

Berdasarakan hasil penelitian dapat dilihat bahwa rerata kadar LDL lebih rendah daripada kadar HDL pada kelompok tiga hingga lima. Hal ini sesuai dengan penelitian oleh Wang pada tahun 2017 dimana kedelai diketahui memiliki kandungan isoflavon yang dapat menyebabkan penurunan kadar LDL, Trigliserida, kolesterol total dan kenaikan kadar HDL yang disebabkan karena adanya mekanisme yang membalikkan transportasi kolesterol dengan melalui persinyalan PPAR serta Liver X Receptor (LXR) dan penghambatan pensinyalan SREBP-1c. ${ }^{6}$ Isoflavon juga dapat berprean sebagai aktivator PPAR $\gamma$ yang dapat menghambat proses persinyalan potent pro-inflammatory nuclear factor seperti nuclear factor kappa-light-chain-enhancer of activated $B$ cells (NFkB). Isoflavon pada kedelai sendiri juga memberikan dampak langsung pada pencegahan disfungsi endotel, stress oksidatif serta penghindaran proses inflamasi, dimana proses tersebut sangat berkaitan erat dengan patogenesis jantung koroner. Dimana dalam patogenesis dari jantung koroner sendiri kadar LDL yang tinggi dapat terakumulasi pada subendothelial pembuluh darah serta mengalami oksidasi sehingga menghasilkan Oxidise $L D L$ (Ox-LDL) yang akan di fagositosis oleh makrofag. Bila jumlah Ox-LDL yang difagosit oleh makrofag cukup banyak maka maktofag akan membentuk foam cell yang dapat terakumulasi sehingga membentuk sumbatan pada pembuluh darah. ${ }^{6,7}$

Penambahan formulasi SMEDDS terhadap ekstrak kedelai memberikan beberapa keuntungan seperti 
meningkatkan kelarutan serta bioavailabilitas dari isoflavon yang terkandung dalam kedelai. Formulasi SMEDDS dapat meningkatkan kelarutan obat dan penyerapan dengan memperluas area permukaan interfacial menjadi lebih luas. Bahan bahan penyusun SMEDDS sendiri terdiri dari komponen minyak, surfaktan, cosurfactant dan bahan aktif itu sendiri. Dimana minyak merupakan komponen yang sangat penting dari SMEDDS dimana minyak berperan sebagai peningkat solubilisasi dan akses bagi obat yang sulit terlaru dalam air untuk masuk ke dalam sirkulasi limfatik. Surfaktant berperan untuk melarutkan cairan hidrofobik dalam formulasi ini sehingga memungkinkan senyawa hidrofobik untuk terlarut lebih memadai. ${ }^{4,8}, 9$

Berdasarkan penelitian terdahulu, formulasi SMEDDS telah terbukti dapat meningkatkan oral bioavailabilitas dari albendazole, carbamazepine, prednisone dan HL235. ${ }^{10-13}$ SMEDDS diketahui juga dapat meningkatkan deposit obat prednisolone pada daerah inflamsi sehingga menyediakan efek yang lebih baik bagi pasien. Kemampuan SMEDDS untuk membentuk oil-inwater microemulsion pada saluran cerna menyediakan luas permukaan yang lebih lebar sehingga mempermudah kerja enzim lipase pankreas untuk menghidrolisis trigliserida dan membantu pelepasan obat lebih cepat sehingga terbentuk micelles yang mengandung obat lebih banyak. Hal ini menyebabkan penyerapan obat dari saluran pencernaan menjadi lebih mudah dan meningkatkan ketersediaan obat di sirkulasi limfatik dan dalam darah, bahkan pada beberapa kasus dilaporkan bahwa obat yang dibawa oleh emulsi oil-in-water yang terbentuk oleh selfemulsifying formulation dapat langsung menembus membaran usus tanpa melalui proses metabolisme oleh enzim lipase. ${ }^{10-13}$

Formulasi SMEDDS diketahui juga dapat meningkatkan bioavailabitilitas bahan aktif puerarin yang diekstrak dari Pueraria lobata (Willd) bila dibandingkan dengan puerarin tablet. Namun pembuatan formulasi SMEDDS memiliki keterbatasan terutama dalam pemilihan surfaktant yang dipakai, sebab harus memperhatian unsur keamanan dari zat tersebut serta kemampuannya untuk mengikar zat aktif. Hal ini lah yang menjadi salah satu keterbatasan dari metode SMEDDS. ${ }^{14}$

Dalam penelitian ini tidak ditemukan adanya perbedaan yang signifikan antara kadar dari HDL dan LDL antar kelompok. Hal ini dapat disebabkan karena lama pemberian formulasi SMEDDS yang cukup singkat sehingga efek dari pemberian SMEDDS belum muncul secara maksimal pada kelompok 3,4 dan 5. Selain itu kemungkinan lainnya adalah tingkat konsentrasi yang pada formulasi yang belum dapat memberikan pengaruh kepada kadar HDL dan LDL hewan coba secara maksimal sehingga perlu diteliti lebih lanjut terkait dengan dosis efektif dari formulasi SMEDDS ekstrak biji kedelai ini.

\section{SIMPULAN}

Formulasi SMEDDS ekstrak biji kedelai tidak menunjukkan kemampuan untuk penurunan kadar LDL ataupun kenaikan kadar HDL pada tikus model penyakit jantung koroner. Hal ini dapat disebabkan karena kurangnya jangka waktu pemberian formulasi SMEDDS. Sehingga untuk penelitian selanjutnya dapat diperlama jangka waktu pemberian formulasi SMEDDS serta dilakukan penelitian lanjutan terkait dosis efektif dari formulasi SMEDDS ekstrak biji kedelai

\section{KONFLIK KEPENTINGAN}

Penulis menyatakan bahwa penelitian ini bebas dari berbagai konflik kepentingan.

\section{ETIKA PENELITIAN}

Ethical clearance dari penelitian ini dikeluarkan oleh Komisi Etik Penelitian Fakultas Kedokteran Universitas Udayana Denpasar dengan nomor surat 1862/ UN14.2.2.VII.14/LT/2021 tertanggal 26 Juli 2021.

\section{PENDANAAN}

Penelitian ini mendapatkan dana dari Direktorat Jenderal Pendidikan Tinggi, Riset dan Teknologi sebagai bagian dari proses pendanaan Program Kreativitas Mahasiswa tahun 2021.

\section{KONTRIBUSI PENULIS}

Semua penulis berkontribusi secara merata dalam persiapan, pelaksanaan serta publikasi penelitian

\section{DAFTAR PUSTAKA}

1. Kemenkes RI. Situasi kesehatan jantung. Pusat data dan Informasi Kementeri Kesehatan RI. 2014.

2. Yang Y, Cai L, Ma R, Xu Y, Tong Y, Huang Y, et al. Erratum: Yang, Y.; et al. A Novel Roseosiphophage Isolated from the Oligotrophic South China Sea. Viruses 2017, 9, 109. Viruses. 2019;11(8):734. Available from: https://pubmed.ncbi.nlm.nih.gov/31398906

3. Swart AC, Johannes ID, Sathyapalan T, Atkin SL. The Effect of Soy Isoflavones on Steroid Metabolism. Front Endocrinol (Lausanne). 2019;10:229. Available from: https://pubmed. ncbi.nlm.nih.gov/31031706

4. Akula S, Gurram AK, Devireddy SR. SelfMicroemulsifying Drug Delivery Systems: An Attractive Strategy for Enhanced Therapeutic Profile. Int Sch Res Not. 2014;2014:964051. Available from: https://pubmed.ncbi.nlm.nih. gov/27382619

5. Wiwiek IA, Martodihardjo S, . S, . J, Ngurah Budiana IGM, . M. Preparation and In-Vitro characterization of Self-Nano emulsifying system of C- Phenylcalix-[4]-Resorcinaryl Octacinnamate and C-Methylcalix-[4]Resorcinaryl Octabenzoate as ultraviolet absorbers. Bali Med J. 2017;6(3):569. Available from: http://dx.doi.org/10.15562/bmj.v6i3.699

6. Wang S, Wang Y, Pan M-H, Ho C-T. Antiobesity molecular mechanism of soy isoflavones: weaving the way to new therapeutic routes. Food Funct. 2017;8(11):3831-46. Available from: http://dx.doi.org/10.1039/c7fo01094j

7. Rahayu S, Amrin A. Pengaruh Intervensi Nonfarmakologi Dan Farmakologi Terhadap Penurunan Intensitas Nyeri Pada Pasien Penyakit Jantung Koroner Di Ruang ICCU RSU Kota Langsa Tahun 2012. J Keperawatan Glob. 2016;1(1). Available from: http://dx.doi. org/10.37341/jkg.v1i1.9

8. Rahayu WM, Astuti E. Pengaruh Proses Pengolahan dan Penyangraian Biji Terhadap Aktivitas dan Kandungan Senyawa Antioksidan Sari Kedelai Hitam Mallika (Glycine Max). Chem J Tek Kim. 2017;4(2):59. Available from: http://dx.doi.org/10.26555/chemica.v4i2.9105

9. Kim DS, Cho JH, Park JH, Kim JS, Song ES, Kwon J, et al. Self-microemulsifying drug delivery system (SMEDDS) for improved oral delivery and photostability of methotrexate. Int J Nanomedicine. 2019;14:4949-60. Available from: https://pubmed.ncbi.nlm.nih. gov/31308665

10. Bansode ST, Kshirsagar SJ, Madgulkar AR, Bhalekar MR, Bandivadekar MM. Design and development of SMEDDS for colonspecific drug delivery. Drug Dev Ind Pharm. 2015;42(4):611-23. Available from: http:// dx.doi.org/10.3109/03639045.2015.1062510 
11. Visetvichaporn V, Kim K-H, Jung K, Cho Y-S, Kim D-D. Formulation of selfmicroemulsifying drug delivery system (SMEDDS) by D-optimal mixture design to enhance the oral bioavailability of a new cathepsin K inhibitor (HL235). Int J Pharm. 2020;573:118772. Available from: http://dx.doi. org/10.1016/j.ijpharm.2019.118772

12. Sawatdee S, Atipairin A, Sae Yoon A, Srichana T, Changsan N, Suwandecha T. Formulation Development of Albendazole-Loaded SelfMicroemulsifying Chewable Tablets to Enhance
Dissolution and Bioavailability. Pharmaceutics. 2019;11(3):134. Available from: https:// pubmed.ncbi.nlm.nih.gov/30897738

13. Zhang N, Zhang W, Jin Y, Quan D. Studies on preparation of carbamazepine (CBZ) supersaturatable self-microemulsifying (S-SMEDDS) formulation and relative bioavailability in beagle dogs. Pharm Dev Technol. 2010;16(4):415-21. Available from: http://dx.doi.org/10.3109/10837451003774419

14. Zhang L. Pharmacokinetics and drug delivery systems for puerarin, a bioactive flavone from traditional Chinese medicine. Drug Deliv. 2019;26(1):860-9. Available from: https:// pubmed.ncbi.nlm.nih.gov/31524010

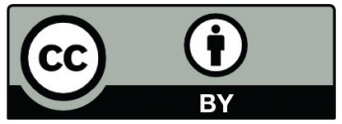

This work is licensed under a Creative Commons Attribution 